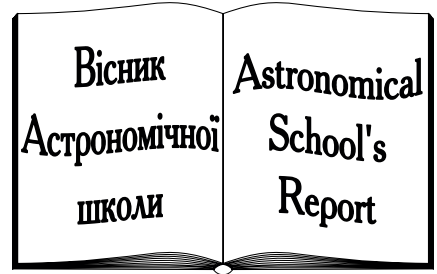

ISSN 2411-6602 (Online)

ISSN 1607-2855 (Print)

Volume $16 \bullet$ Issue $1 \bullet \mathbf{2 0 2 0} \quad$ P. $16-21$

https://doi.org/10.18372/2411-6602.16.03

UDC $520: 523.34$

\title{
Telescope pointing software for slit spectroscopy of the lunar exosphere
}

\author{
Yu.I. Velikodsky ${ }^{1,2 *}$, A.A. Berezhnoy ${ }^{3}$, S.F. Velichko ${ }^{2,4}$, Yu.V. Pakhomov \\ ${ }^{1}$ National Aviation University, Liubomyra Huzara Ave. 1, 03058 Kyiv, Ukraine \\ ${ }^{2}$ Institute of Astronomy, V.N. Karazin Kharkiv National University, Sumska St. 35, 61022 Kharkiv, Ukraine \\ ${ }^{3}$ Sternberg Astronomical Institute, Moscow State University, Universitetskij pr. 13, 119991 Moscow, Russia \\ ${ }^{4}$ IC AMER Observatory of National Academy of Sciences of Ukraine, Akademika Zabolotnoho St. 27, 03143 Kyiv, \\ Ukraine \\ ${ }^{5}$ Institute of Astronomy, Russian Academy of Sciences, Pyatnitskaya St. 48, 119017 Moscow, Russia
}

Detailed description of the original pointing software used for spectral observations of the lunar exosphere is given. The software allows to point the spectrograph of 2-m telescope of Terskol Observatory inside and outside the lunar disk with accuracy of about $2^{\prime \prime}$. Observations of Na lines in the exosphere of the Moon on January 8 and October 7 , 2017, do not reveal quick variability of Na lines at time scales of about 20 minutes. On January 8, 2017, the intensity of $\mathrm{Na}$ lines above the south pole of the Moon was stronger than that above the north pole of the Moon.

Keywords: telescope pointing; Moon; exosphere; spectroscopy; software.

\section{INTRODUCTION}

Lunar exosphere is a weak extended object which is not observed in the continuum, but reveals an emission in lines of species as $\mathrm{Na}, \mathrm{K}, \mathrm{Li}, \mathrm{Ba}, \mathrm{Ca}, \mathrm{Mn}$, Ti, etc. Earth-based observations of the lunar exosphere make use different techniques including coronographic imaging [3, 5], Fabry-Pérot spectroscopy [7, 8], and slit spectroscopy $[1,10,12]$. The last is more suitable for simultaneously measuring lines of several species in wide spectral range. A slit in such observations has a size of about several arcseconds and can be pointed as close to the lunar limb as its size, orientation, and light scattering from the lunar disk allow. The intensity gradient for some lines can be high in the neighborhood of lunar limb, hence the accuracy of telescope pointing is very important in this case. However, some telescopes have an unsatisfied accuracy of automatic pointing. Moreover, a standard automatic guide can work only with stars, but the Moon moves unevenly with respect to stars. Thus, a "lunar" telescope guidance on two axes should be used as well as a manual guide for corrections. This also requires a manual correction when pointing to objects inside and outside the lunar disk. Star-like objects and nebulas allow such a correction by visual alignment of the slit center to a point of maximum brightness. But the lunar exosphere and most lunar-surface features are too homogenous for such a visual correction. The idea of this work is to use the CCD image of lunar disk from a guide of telescope for the accurate movement of the telescope from a lunar surface feature to the point in the exosphere with specified position angle and distance from the limb. We developed an auxiliary software moon_points to help an observer in such an operation as applied to 2-m Zeiss telescope of Terskol Observatory (International Center for Astronomical, Medical and Ecological Research (IC AMER) of the National Academy of Sciences of Ukraine and Terskol branch of Institute of Astronomy of Russian Academy of Sciences, Kabardino-Balkaria, Russia) equipped by Multi Mode Cassegrain Spectrograph (MMCS). At the same time, we present the results of the first observations with the software as well as without it to compare them.

\section{ALGORITHM AND SOFTWARE}

The manual guide of $2-\mathrm{m}$ telescope at Terskol Observatory is equipped by CCD camera with resolution of $2.3^{\prime \prime}$ and field of $29^{\prime} \times 19^{\prime}(765 \times 510 \mathrm{px})$. This allows to point the telescope to any object inside or outside the lunar disk with accuracy of about $2^{\prime \prime}$ using the guide CCD images of the lunar disk. To do this, we need a following information:

1) the coordinates of the slit $x_{\mathrm{s}}, y_{\mathrm{s}}(\mathrm{px})$ in a guide CCD image, i.e. pixel coordinates of the point where the center of spectrograph slit is pointing;

2) the coordinates of the lunar disk's center $x_{\mathrm{m}}, y_{\mathrm{m}}(\mathrm{px})$;

3) the radius of the lunar disk $R_{\mathrm{m}}(\mathrm{px})$;

*Velikodsky Yuri Ivanovych; $₫$ yuri.velikodsky@gmail.com 
4) the position angle $P_{\mathrm{m} Y}(\mathrm{deg})$ of the Moon with respect to the vertical $Y$ axis.

Using this information, we can calculate an offset $\Delta x, \Delta y$ (px) with respect to the current position for pointing the spectrograph to any specified object as described below. To move the telescope according to this offset, we propose to use a control point at the lunar disk, e.g. any small contrast crater which can be positioned with accuracy of about $1 \mathrm{px}\left(2.3^{\prime \prime}\right)$. Thus, coordinates of the control point $x_{\mathrm{c}}, y_{\mathrm{c}}$ (px) should be measured in addition to the information listed above. Then, the observer should move the telescope so that the control point has pixel coordinates $x_{\mathrm{c}}-\Delta x, y_{\mathrm{c}}-\Delta y$. As a result, the spectrograph is pointed to the specified object.

We present here the software (Python script) for automation of this process. The script automatically calculates $x_{\mathrm{m}}, y_{\mathrm{m}}, R_{\mathrm{m}}$ analyzing a guide image of the Moon. The position angle $P_{\mathrm{m} Y}$ is also obtained from two Moon's images with a mutual offset in specified direction (see the description below). To use the software, the observer should follow the algorithm:

1. Set the stellar telescope guidance. Point the spectrograph slit to any star near of the Moon (because coordinates of the slit depend on the telescope orientation). Write the pixel coordinates of the star in a guide image $x_{\mathrm{s}}, y_{\mathrm{s}}$ (counted from the top-left corner) with accuracy of $1 \mathrm{px}$ into the text file slit.dat (separated by whitespace).

2. Set the lunar telescope guidance according to the current movement of the Moon. Point the guide to the Moon and save two frames as FITS files (Moon0.fit and Moon.fit). The Moon should be visible with the most part of the limb (not the terminator) in both frames. Offset of Moon's position between two frames should be about 200 px along only one axis (right ascension or declination). Such an offset is enough for accurate determining the position angle of the Moon, while the larger part of lunar disk still fits in both frames and allows a good image co-registration.

3. Find a small contrast crater (the control point) in the image Moon.fit and write its coordinates $x_{\mathrm{c}}, y_{\mathrm{c}}$ with accuracy of 1 px to the text file crater.dat (separated by whitespace).

4. Place all files into folder data which is located in the folder of the script moon_points.py (or moon_points.exe).

5. Run the program moon_points.py (or moon_points.exe). It outputs a table with results (to the screen and to file result.dat). The last two columns contain the pixel coordinates where the observer should place the crater (the control point) $x_{\mathrm{c}}-\Delta x_{i}, y_{\mathrm{c}}-\Delta y_{i}$ for each point of observation (indexed by $i$ ). If the coordinates are outside of the frame, the observer should return to step 3 and select another crater.

6. Acquire a spectrum of the object in the main focus for each $i$.

7. During the exposure (or before it), the observer can control visually the accuracy of the moon_points' calculations. The program generates the picture Moon_Points.png simultaneously with the main results of result.dat. This picture (presented in Fig. 1) shows the frame with Moon's image, a blue circle of the autodetected limb, and red crosses of the pre-calculated observational points. If the limb is detected incorrectly, the observer should return to step 2 and select another position of the Moon (with longer part of the limb) for better limb detection.

Furthermore, the observer should prepare 3 more files in data folder before beginning the observation:

1) ephemeris.dat with the ephemeris of the Moon on observation dates with step $1^{\text {h }}$ (with quantities:

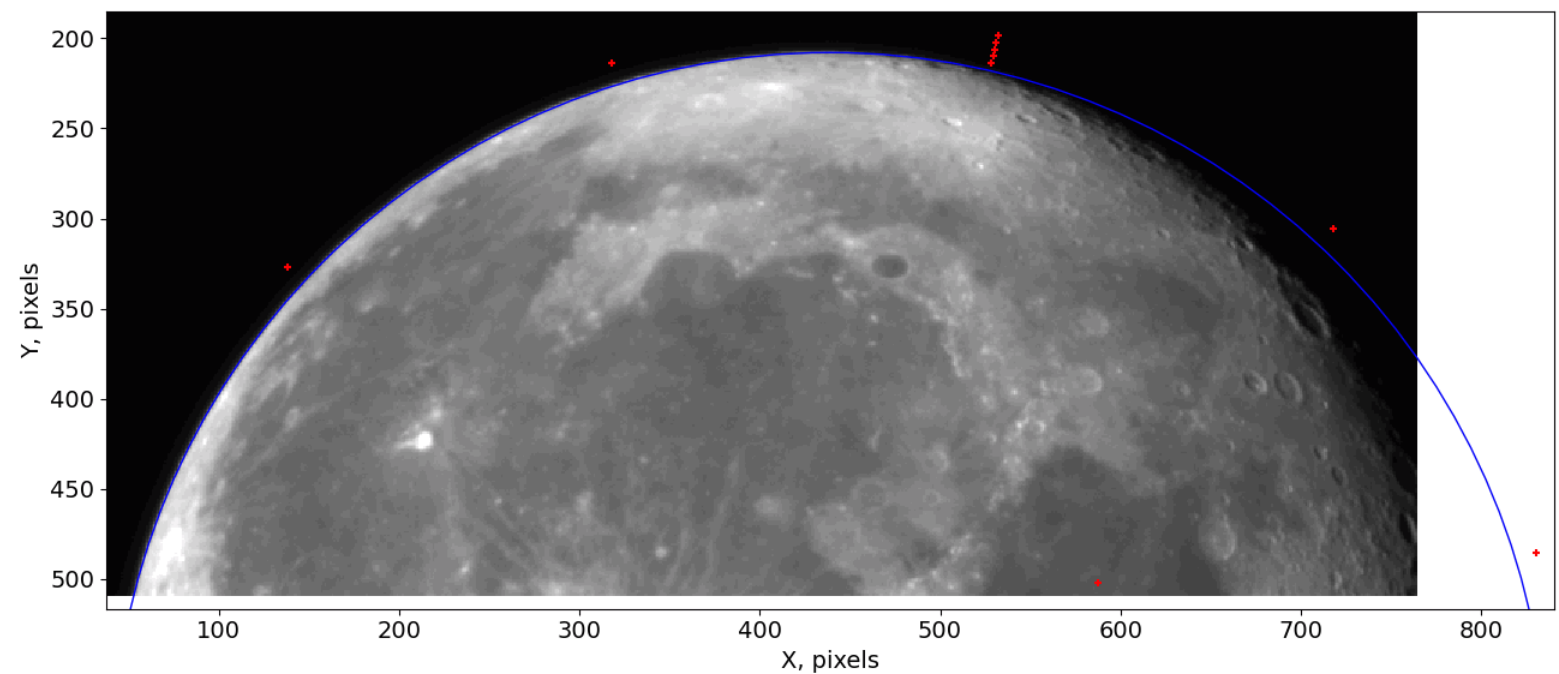

Fig. 1. A guide image of the Moon (October 7, 2017, 18:57 UT). Blue circle is an autodetected limb. Red crosses are points of observation in the exosphere and in Mare Serenitatis. Coordinates are counted from the top-left corner of CCD image (outside of the figure). 
"target angular diameter", "observer sub-lon \& sub-lat", "north pole position angle \& distance”). The file can be obtained from JPL Horizons Ephemeris System [4] using a following request (example for our observation on October 7, 2015):

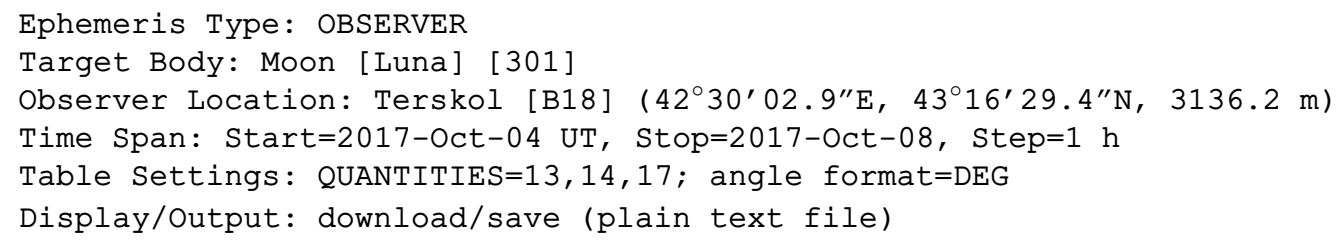

2) points_limb.dat with positions of observation points in the lunar exosphere (with respect to the li$\mathrm{mb})$. The file contains two columns named as "PA_deg" and "h_arcsec". Each row corresponds to one observation point and consists of tab-separated values of the position angle $P_{i}$ (deg) of the point counterclockwise from the north pole and height $h_{i}$ (angular distance) above the limb (arcsec), respectively;

3) points_moon.dat with coordinates of observation points at the lunar surface (for absolute calibration). The file contains three columns named as "Lat_deg", "Lon_deg", "Elev_km". Each row corresponds one observation point and consists of tab-separated values of the selenographic latitude (deg), longitude (deg), and elevation $(\mathrm{km})$, respectively.

Calculation algorithm. At the first step, the program moon_points converts the selenographic coordinates from points_moon.dat to the parameters $P_{i}, h_{i}$ and adds them to the list of points taken from points_limb.dat. The calculation is performed with taking into account a finite distance from the observer to the Moon (the "target angular diameter" and "observer's sub-lon \& sub-lat coordinates" from the ephemeris are used). Note that parameter $h_{i}$ is negative for lunar-surface points.

The next step is autodetecting the lunar disk $\left(x_{\mathrm{m}}, y_{\mathrm{m}}, R_{\mathrm{m}}\right)$ in the image Moon.fit. The program build a circle as a result of limb detection. The circle is fitted using the image points with highest gradient magnitude [2]. We calculate the gradient magnitude using Gaussian derivatives (with the method ndimage.gaussian_gradientidxmagnitude() of library SciPy). As a result, the coordinates of the circle's center and its radius are assigned to $x_{\mathrm{m}}, y_{\mathrm{m}}$, and $R_{\mathrm{m}}$, respectively.

Then images Moon0.fit and Moon.fit are co-registered using the phase correlation method [6] to obtain the mutual offset $\Delta x_{0}, \Delta y_{0}(\mathrm{px})$. The method includes the substep of obtaining the coordinates of the point-like object (after the inverse Fourier transformation). For this substep, we use fitting with a paraboloid function in $3 \times 3$ px vicinity near the maximum to achieve a subpixel accuracy. We also assume that direction of CCD $Y$ axis is close to meridional and the CCD position angle $P_{\mathrm{c}}$ is close (though not equal) to zero. Thus, the program can detect which offset was used by the observer: if $\Delta x_{0}>\Delta y_{0}$ then the offset is in right ascension; otherwise it is in declination. And the CCD position angle can be obtained as $P_{\mathrm{c}}=\arctan \left(\frac{\Delta y_{0}}{\Delta x_{0}}\right)$ or $P_{\mathrm{c}}=-\arctan \left(\frac{\Delta x_{0}}{\Delta y_{0}}\right)$, respectively. Consequently, the position angle of the Moon with respect to the $Y$ axis can be found as $P_{\mathrm{m} Y}=P_{\mathrm{m}}-P_{\mathrm{c}}$, where $P_{\mathrm{m}}$ is the north pole position angle of the Moon from the ephemeris.

At the next step, coordinates of observational points $x_{i}, y_{i}$ are calculated as

$$
x_{i}=x_{\mathrm{m}}-r_{i} \sin \left(P_{\mathrm{m} Y}+P_{i}\right), \quad y_{i}=y_{\mathrm{m}}-r_{i} \cos \left(P_{\mathrm{m} Y}+P_{i}\right),
$$

where $r_{i}=R_{\mathrm{m}}+\frac{h_{i}}{s}$ is the distance of the point from the Moon's center (px), s is an image scale (arcsec/px).

Finally, the offset for each point is obtained:

$$
\Delta x_{i}=x_{i}-x_{\mathrm{s}}, \quad \Delta y_{i}=y_{i}-y_{\mathrm{s}},
$$

and new coordinates of the control point for each observation point are calculated as was described above:

$$
x_{\text {new }}=x_{\mathrm{c}}-\Delta x_{i}, \quad y_{\text {new }}=y_{\mathrm{c}}-\Delta y_{i}
$$

The observer moves the control point to the point with these coordinates and, as a result, the spectrograph is pointed to $i$-th observation point.

Source code. We present the Python code of the program moon_points in Supplementary data ${ }^{1}$. Examples of all auxiliary files listed above are also added in the same zip-archive. User can simply run the script and it will perform the calculations for our observation date October 7, 2017, and will produce Fig. 1.

The program is freely distributed as a Python script. In addition, we also use the executable file for MS Windows (moon_points.exe, not included in the Supplementary data) compiled using Pylnstaller (https:// www.pyinstaller.org/) for the case when an observer does not have the installed Python with the libraries.

We note that the code contains our simple realization of reading images from FITS files [9]. It can be replaced, for example, by Astropy methods [11] if any problems will arise with FITS files from another source. The aim of our realization is to minimize a size of the executable file.

\footnotetext{
${ }^{1}$ http://astro.nau.edu.ua/supplementary/2020_V.16_Iss.1/Velikodsky_et_al/moon_points.zip 


\section{OBSERVATIONS AND RESULTS}

Spectroscopic observations of NaI D1 (5895.9 $\AA$ ) and D2 (5890.0 $)$ ) resonance lines in the lunar exosphere were performed on January 8 and October 7, 2017, using the echelle spectrograph MMCS of the 2-m telescope of Terskol Observatory. The slit of the spectrograph has a height of $10^{\prime \prime}$ and a width of $2^{\prime \prime}$. The spectral resolution of used spectrograph was $\lambda / \Delta \lambda=13,500$. The procedure of data analysis is the same as that described in [1]. For calibration purposes several objects on the Moon were observed on January 8 and October 7, 2017.

Observations on January 8, 2017, were performed soon after the maximum of Quadrantid meteor shower on January 3, 2017, at the phase of the Moon equal to 0.8 (Table 1). The software moon_points was not used on January 8, 2017. Telescope pointing was performed manually using an offset from the apparent position of north and south poles. Accuracy of such pointing did not allow to study dependence on the distance from

Table 1. Summary of observations of the lunar exosphere in Na lines on January 8, 2017

\begin{tabular}{|c|c|c|}
\hline Time of observations, UT & $\begin{array}{c}\text { Distance from } \\
\text { the surface, arcsec }\end{array}$ & $\begin{array}{c}\text { Position angle, } \\
\text { degrees }\end{array}$ \\
\hline January 8, 2017, 17:28-17:48 & 30 & 0 \\
January 8, 2017, 17:49-18:09 & 30 & 0 \\
January 8, 2017, 18:10-18:30 & 30 & 0 \\
January 8, 2017, 18:31-18:51 & 30 & 0 \\
January 8, 2017, 19:17-19:37 & 30 & 180 \\
January 8, 2017, 19:39-19:59 & 30 & 180 \\
January 8, 2017, 20:00-20:20 & 30 & 180 \\
January 8, 2017, 20:21-20:41 & 30 & 0 \\
January 8, 2017, 21:07-21:27 & 30 & 0 \\
January 8, 2017, 21:28-21:48 & 30 & 0 \\
January 8, 2017, 21:49-22:09 & 30 & \\
\hline
\end{tabular}

Table 2. Summary of observations of the lunar exosphere in $\mathrm{Na}$ lines on October 7, 2017

\begin{tabular}{|c|c|c|c|c|}
\hline Time of observations, UT & $\begin{array}{c}\text { Distance from } \\
\text { the surface, arcsec }\end{array}$ & $\begin{array}{c}\text { Position angle, } \\
\text { degrees }\end{array}$ & $\begin{array}{c}\text { Na D2 line, } \\
10^{-13} \mathrm{erg} \mathrm{s}^{-1} \mathrm{~cm}^{-2}\end{array}$ & $\begin{array}{c}\text { Na D1 line, } \\
10^{-13} \mathrm{erg} \mathrm{s}^{-1} \mathrm{~cm}^{-2}\end{array}$ \\
\hline October 7, 2017, 20:02-20:22 & 20 & 0 & $3.07 \pm 0.09$ & $1.74 \pm 0.09$ \\
October 7, 2017, 20:29-20:49 & 10 & 0 & $3.10 \pm 0.11$ & $1.67 \pm 0.11$ \\
October 7, 2017, 20:50-21:10 & 30 & 0 & $3.27 \pm 0.08$ & $1.86 \pm 0.08$ \\
October 7, 2017, 21:12-21:32 & 40 & 0 & $3.43 \pm 0.09$ & $2.18 \pm 0.09$ \\
October 7, 2017, 21:35-21:55 & 50 & 30 & $2.97 \pm 0.07$ & $1.87 \pm 0.07$ \\
October 7, 2017, 22:20-22:40 & 30 & 60 & $4.48 \pm 0.09$ & $2.92 \pm 0.09$ \\
October 7, 2017, 22:43-23:03 & 30 & 300 & $1.05 \pm 0.10$ & $3.23 \pm 0.10$ \\
October 7, 2017, 23:20-23:40 & 30 & 330 & $1.27 \pm 0.05$ & $0.71 \pm 0.04$ \\
October 7, 2017, 23:42- & 30 & & & $0.76 \pm 0.05$ \\
October 8, 2017, 0:02 & & & \\
\hline
\end{tabular}

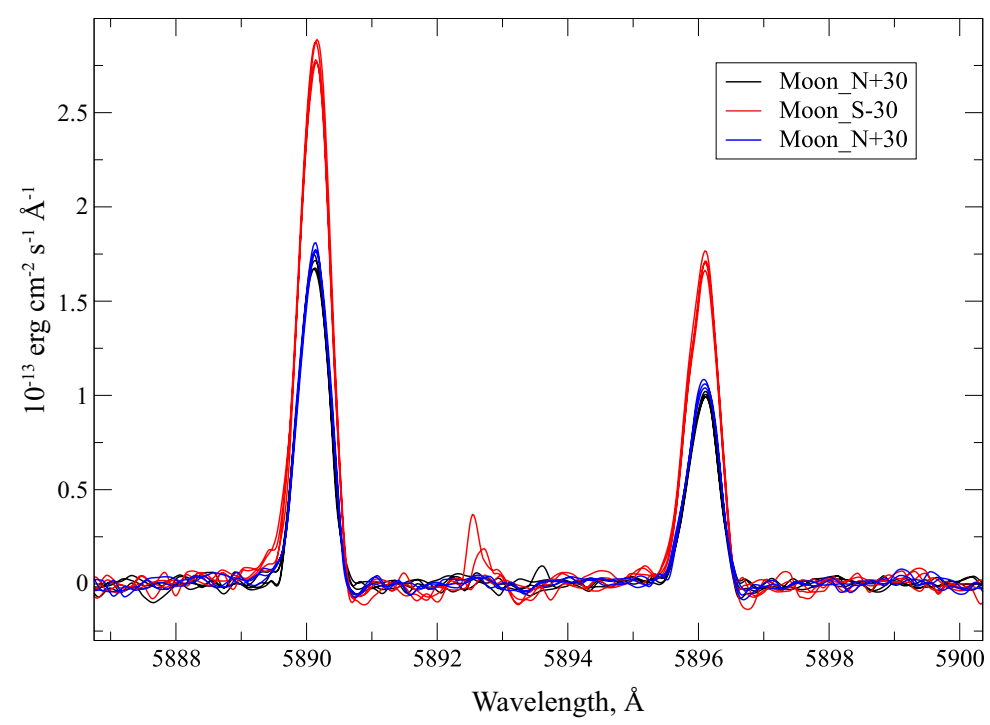

Fig. 2. Spectra of the lunar exosphere in the vicinities of Na lines obtained on January 8, 2017. Red lines show spectra obtained at $30^{\prime \prime}$ above the south pole of the Moon while black and blue lines show spectra obtained at $30^{\prime \prime}$ above the north pole of the Moon. 
limb. The distance of $30^{\prime \prime}$ in Table 1 is approximate.

Quick variability of Na lines on time scale of about 20 minute (duration of obtaining of each spectrum) was not detected (see Fig. 2). Fluxes in Na lines were stable within about $5 \%$ of error of measurements. It is interesting to note that $\mathrm{Na}$ lines were stronger above south pole in comparison with that of north pole (see Fig. 2). It can be explained by higher content of surficial $\mathrm{Na}$ in south polar region in comparison with that in north polar region.

Regions in the lunar exosphere observed on October 7, 2017, are shown on Fig. 1. Spectral observations of the lunar exosphere on October 7, 2017, were performed at the phase of the Moon of 0.95 before the maximum of the Draconid meteor shower occurred on October 8, 2017 (Table 2). The software moon_points was successfully used on October 7, 2017, and allowed to observe the exosphere extremely close to the limb $\left(10^{\prime \prime}\right)$ as well as to use a minimal step $\left(10^{\prime \prime}\right)$ between points along the radial direction. Moreover, using moon_points allowed to study the latitude dependence by observations of points with different position angles near the limb. Absolute calibration by lunar albedo was also more accurate because the moon_points allowed to point the spectrograph to a desired area in Mare Serenitatis using specified selenographic coordinates.

Observations at the same position angle at different distances above the limb were performed in too narrow range of distances $\left(10^{\prime \prime}-50^{\prime \prime}\right.$ corresponding to $20-90 \mathrm{~km}$ above the limb). The idea of such observations was to study cold component of $\mathrm{Na}$ atoms thermally desorbed from the surface to the exosphere and having temperature comparable to surface temperature on the Moon, about $200 \mathrm{~K}$. Such temperature corresponds to height scale of $\mathrm{Na}$ atoms of about $50 \mathrm{~km}$. Such gradient of distribution of $\mathrm{Na}$ atoms can be easy detected during observations at $20-90 \mathrm{~km}$ distances above the limb. However, the cold component of $\mathrm{Na}$ atoms has not been detected during these observations. Moreover, we observed increase of the intensity of $\mathrm{Na}$ lines when distance from the limb was increased from $20^{\prime \prime}$ to $40^{\prime \prime}$. Such behavior can be explained by existence of possible instrumental effects, changes of transparency of the Earth's atmosphere and/or errors of absolute calibration.

Observations at different position angles were performed for studies of dependence of the intensity of $\mathrm{Na}$ lines as a function of latitude. Increase of the intensity of $\mathrm{Na}$ lines with decreasing of latitude has been detected during observations at position angles of 0,30 , and 60 degrees. Such results are in agreement with previous observations of $\mathrm{Na}$ in the lunar exosphere [5]. Observations at position angles of 300 and 330 degrees cannot be used for estimated of line-of-sight column densities of $\mathrm{Na}$ atoms because at these position angles a part of the line-of-sight is shadowed by the Moon.

Estimation of line-of-sight column densities of $\mathrm{Na}$ atoms with usage of $g$-factor values as a function of heliocentric velocity of the Moon as well as zenith column densities as a function of temperature of $\mathrm{Na}$ atoms with usage of Chamberlain model are planned to be performed in a forthcoming publication devoted to deeper analysis of these observations.

\section{CONCLUSIONS}

Usage of originally developed pointing software moon_points increased accuracy of pointing to selected regions in the lunar exosphere and on the surface of the Moon. This software is strongly needed for usage of the Moon as a calibration source. Using the manual guide and the software like moon_points is the only way to perform accurate spectral observation of the Moon and its exosphere on 2-m telescope of Terskol Observatory. Preliminary results of single observations of $\mathrm{Na}$ lines in the lunar exosphere on January 8 and October 7, 2017, are presented. Deeper understanding of properties of $\mathrm{Na}$ lunar exosphere as a function of the level of meteoroid activity requires observations of the exosphere for at least 2-3 nights during the activity of a studied meteor shower. Impacts of big meteoroids are able to significantly increase the content of $\mathrm{Na}$ atoms in the lunar exosphere and have not been detected during the performed observations.

Acknowledgements. Observations at the 2-m Terskol telescope were performed under the project "Observations of the lunar atmosphere during lunar eclipses and activity of main meteor showers of the international program "Astro-cosmic research in the Elbrus region. 2015-2020" of the IC AMER.

1. Berezhnoy A.A., Churyumov K.I., Kleshchenok V.V., Kozlova E.A., Mangano V., Pakhomov Yu.V., Ponomarenko V.O., Shevchenko V.V., Velikodsky Yu.I. Properties of the lunar exosphere during the Perseid 2009 meteor shower // Planetary and Space Science. - 2014. - Vol.96. - P.90-98. https://doi.org/10.1016/j.pss.2014.03.008

2. Canny J. A computational approach to edge detection // IEEE Trans. Pattern Anal. Mach. Intell. - 1986. Vol. 8(6). - P.679-698. https://doi.org/10.1109/TPAMI.1986.4767851

3. Flynn B., Mendillo M. A picture of the Moon's atmosphere // Science. - 1993. - Vol.261(5118). - P.184-186. https://doi.org/10.1126/science.261.5118.184

4. Giorgini J.D. Status of the JPL Horizons Ephemeris System // IAU General Assembly, 2015. - Meeting \#29, id.2256293, https://ssd.jpl.nasa.gov/horizons.cgi.

5. Killen R.M., Morgan T.H., Potter A.E., Plymate C., Tucker R., Johnson J.D. Coronagraphic observations of the lunar sodium exosphere January-June, 2017 // Icarus. - 2019. - Vol. 328. - P.152-159.

https://doi.org/10.1016/j.icarus.2019.02.027 
6. Kuglin C.D., Hines D.C. The phase correlation image alignment method // Proc. Int. Conference Cybernetics Society. - 1975. - P.163-165.

7. Kuruppuaratchi D.C.P., Mierkiewicz E.J., Oliversen R.J., Sarantos M., Derr N.J., Gallant, M.A., Rosborough S.A., Freer C.W., Spalsbury L.C., Gardner D.D., Lupie O.L. High-Resolution, Ground-Based Observations of the Lunar Sodium Exosphere During the Lunar Atmosphere and Dust Environment Explorer (LADEE) Mission // Journal of Geophysical Research: Planets. - 2018. - Vol. 123(9). - P.2430-2444. https://doi.org/10.1029/2018JE005717

8. Mierkiewicz E.J., Oliversen R.J., Roesler F.L., Lupie O.L. High-resolution spectroscopy of the lunar sodium exosphere // Journal of Geophysical Research: Space Physics. - 2014. - Vol. 119(6). - P.4950-4956. https://doi.org/10.1002/2014JA019801

9. Pence W.D., Chiappetti L., Page C.G., Shaw R.A., Stobie E. Definition of the flexible image transport system (FITS), version $3.0 / /$ Astronomy and Astrophysics. - 2010. - Vol.524, A42. https://doi.org/10.1051/0004-6361/201015362

10. Potter A.E., Morgan T.H. Discovery of sodium and potassium vapor in the atmosphere of the Moon // Science. 1988. - Vol. 241(4866). - P.675-680. https://doi.org/10.1126/science.241.4866.675

11. Price-Whelan A.M., Sipöcz B.M., Günther H.M. et al. The Astropy project: Building an open-science project and status of the v2.0 core package // The Astronomical Journal. - 2018. - Vol. 156(3). - P.123. https://doi.org/10.3847/1538-3881/aabc4f

12. Stern S.A., Fitzsimmons A., Killen R.M., Potter A.E. A direct measurement of sodium temperature in the lunar atmosphere // 31st Lunar and Planetary Science Conference, March 13-17, 2000, Houston, Texas, USA, abstract No. 1122

\section{Програмне забезпечення наведення телескопа для щілинної спектроскопії місячної екзосфери} Великодський Ю.I. ${ }^{1,2}$, Бережной O.A. ${ }^{3}$, Величко C..$^{2,4}$, Пахомов Ю.В. ${ }^{5}$

${ }^{1}$ Національний авіаційний університет, 03058, м. Київ, проспект Любомира Гузара, 1

${ }^{2}$ Науково-дослідний інститут астрономії Харківського національного університету імені В.Н. Каразіна, 61022, м. Харків, вул. Сумська, 35

${ }^{3}$ Астрономічний інститут ім. Штернберга Московського державного університету, Росія, 119991, м. Москва, Університетський пр. 13

${ }^{4}$ Обсерваторія МЦ АМЕД Національної академії наук України, 03143, м. Київ, вул. Академіка Заболотного, 27

${ }^{5}$ Інститут астрономії Російської академії наук, Росія, 119017, м. Москва, вул. П'ятницька, 48

Представлено детальний опис оригінального програмного забезпечення наведення телескопа, яке використовується для спектральних спостережень місячної екзосфери. Програмне забезпечення дозволяє наводити спектрограф 2-метрового телескопа обсерваторії Терскол як на деталі всередині місячного диска, так і поруч 3 ним 3 точністю близько $2^{\prime \prime}$. Програмне забезпечення було успішно використане 7 жовтня 2017 року та дозволило спостерігати екзосферу досить близько до лімба Місяця $\left(10^{\prime \prime}\right)$, а також використовувати мінімальний крок $\left(10^{\prime \prime}\right)$ між точками спостереження у радіальному напрямку. Крім того, використання програми дозволило вивчити широтну залежність шляхом спостереження точок з різними позиційними кутами уздовж лімбу. Абсолютне калібрування за місячним альбедо стало також більш точним, оскільки програма дозволила направляти спектрограф у бажану область поверхні Місяця, використовуючи задані селенографічні координати. Використання ручного гіда та програмного забезпечення, подібного до представленого, є єдиним способом точного спектрального спостереження Місяця та його екзосфери на 2-м телескопі обсерваторії Терскол. У роботі представлено код програми та детальний опис алгоритму iii роботи. Спостереження ліній Na в екзосфері Місяця 8 січня та 7 жовтня 2017 року не виявили швидких варіацій ліній $\mathrm{Na}$ в масштабах часу близько 20 хвилин. 8 січня 2017 року інтенсивність ліній a над південним полюсом Місяця була більшою, ніж над північним полюсом.

Ключові слова: наведення телескопа; Місяць; екзосфера; спектроскопія; програмне забезпечення.

\section{Программное обеспечение наведения телескопа для щелевой спектроскопии лунной экзосферы} Великодский Ю.И. ${ }^{1,2}$, Бережной А.A. ${ }^{3}$, Величко С..$^{2,4}$, Пахомов Ю.В. ${ }^{5}$

${ }^{1}$ Национальный авиационный университет, 03058, г. Киев, проспект Любомира Гузара, 1

${ }^{2}$ Научно-исследовательский институт астрономии Харьковского национального университета им. В.Н. Каразина, 61022 , г. Харьков, ул. Сумская, 35

${ }^{3}$ Астрономический институт им. Штернберга Московского государственного университета, Россия, 119991, г. Москва, Университетский пр., 13

${ }^{4}$ Обсерватория МЦ АМЭИ Национальной академии наук Украины, 03143, г. Киев, ул. Академика Заболотного, 27

${ }^{5}$ Институт астрономии Российской академии наук, Россия, 119017, г. Москва, ул. Пятницкая, 48

Представлено подробное описание оригинального программного обеспечения наведения телескопа, которое используется для спектральных наблюдений лунной экзосферы. Программное обеспечение позволяет наводить спектрограф 2 -метрового телескопа обсерватории Терскол как на детали лунного диска, так и рядом с диском с точностью порядка 2". Наблюдения линий Na в экзосфере Луны 8 января и 7 октября 2017 года не выявили быстрых вариаций линий Na в масштабах времени около 20 минут. 8 января 2017 года интенсивность линий а над южным полюсом Луны была больше, чем над северным полюсом.

Ключевые слова: наведение телескопа; Луна; экзосфера; спектроскопия; программное обеспечение.

Надійшла до редакції / Received

Прийнята до друку / Accepted 3.08.2020 